\title{
UMBATRA
}

Indonesian Journal of Anthropology

Volume 3 (1) Juli 2018 || eISSN 2528-1569 | pISSN 2528-2115 || http://jurnal.unpad.ac.id/umbara

DOI : 10.24198/umbara.v3i1.25670

\section{Peran Badan Usaha Milik Desa (BUMDes) dalam Peningkatan Kesejahteraan Masyarakat Di Desa Ponggok, Kabupaten Klaten}

\author{
Fajar Subehi ${ }^{1}$, Asma Luthfi $^{2}$, Moh. Solehatul Mustofa ${ }^{3}$, Gunawan $^{4}$ \\ Jurusan Sosiologi dan Antropologi, Fakultas Ilmu Sosial, Universitas Negeri Semarang \\ 'subehifano@gmail.com \\ ²asma_luthfi@mail.unnes.ac.id \\ 33ms_mustofa@rocketmail.com \\ ^4goenantro@mail.unnes.ac.id
}

\begin{abstract}
Desa Ponggok is one of the independent villages in Indonesia. This village can manage its natural potential through Village-Owned Enterprises (BUMDes) to improve welfare and empower its society. This research describes in detail the efforts made by the government and villagers in improving welfare through various businesses managed under BUMDes. This research uses qualitative, descriptive methods. Data collection techniques are carried out through involved observation, in-depth interviews, and documentation. This study found that managing the assets and potential of the village through BUMDes Tirta Mandiri which involved the village community had succeeded in improving the welfare of the residents was not simple. Several factors hinder and encourage the success of this effort, including technology, human resources, and business competition. However, a solid collaboration between the government and villagers has proven to be able to overcome obstacles and make BUMDes as facilitators in the socio-economic empowerment of its citizens.
\end{abstract}

Keywords: Village assets, BUMDes, community welfare

\begin{abstract}
Abstrak
Desa Ponggok adalah salah satu desa mandiri di Indonesia. Desa ini mampu mengelola potensi alam yang dimilikinya melalui Badan Usaha Milik Desa (BUMDes) untuk meningkatkan kesejahteraan dan memberdayakan masyarakatnya. Penelitian ini menggambarkan secara rinci upaya yang dilakukan oleh pemerintah dan warga desa dalam peningkatan kesejahteraan melalui aneka usaha yang dikelola di bawah BUMDes. Penelitian ini menggunakan metode kualitatif, deskriptif. Teknik pengumpulan data dilakukan melalui pengamatan terlibat, wawancara mendalam, dan dokumentasi. Penelitian ini menemukan bahwa pengelolaan aset dan potensi desa melalui BUMDes Tirta Mandiri yang melibatkan masyarakat desa telah berhasil meningkatkan kesejahteraan warga tidaklah sederhana. Ada beberapa faktor yang menghambat dan mendorong keberhasilan upaya ini, di antaranya faktor teknologi, sumber daya manusia, dan persaingan usaha. Namun, kolaborasi pemerintah dan warga desa yang solid
\end{abstract}


terbukti mampu mengatasi hambatan dan menjadikan BUMDes sebagai fasilitor dalam pemberdayaan sosial-ekonomi warganya.

Kata kunci: Aset desa, BUMDes, kesejahteraan masyarakat

\section{Pendahuluan}

Desa Ponggok adalah sebuah desa di Kecamatan Polanharjo, Kabupaten Klaten, Provinsi Jawa Tengah. Desa ini memiliki potensi dalam bidang pertanian, perikanan, dan pariwisata dan kini menjadi salah satu percontohan desa mandiri di Indonesia. Namun, keberhasilan desa ini tidak terjadi secara singkat dan mudah. Mulanya, masyarakat Desa Ponggok sebagian besar berprofesi sebagai petani dengan penghasilan rendah dan tidak cukup untuk kehidupan rumah tangga sehari-hari. Akibatnya, banyak warga yang berhutang pada rentenir sebagai jalan pintas untuk membeli kebutuhan pokok dan perlengkapan sekolah anak. Lambat laun, perekonomian warga makin terpuruk akibat jeratan hutang mereka pada rentenir. Situasi ini mendorong pemerintah desa menggunakan tujuh puluh persen dari dana hibah desa yang diberikan oleh pemerintah untuk melunasi hutang para petani terhadap rentenir.

Pada 2009, Desa Ponggok hanya memiliki pendapatan desa sebesar 14 juta rupiah saja per bulan. Pendapatan yang minim ini, mendorong pemerintah desa berinisiatif mengembangkan usaha di bawah koordinasi desa semacam Badan Usaha Milik Desa (BUMDes) sebagai solusi untuk meningkatkan kesejahteraan dan memberdayakan masyarakat. Pendirian usaha desa ini atas kesepakatan pemerintah dan warga masyarakat. Pendirian usaha desa di Ponggok ini dilakukan jauh sebelum peluncuran program resmi BUMDes oleh pemerintah.

Usaha BUMDes Ponggok berupa pemanfaatan potensi alam terutama sumber daya air yang dikelola menjadi komoditas pariwisata dengan nama usaha "Tirta Mandiri". Selain bertujuan meningkatkan penghasilan desa dan warga, kegiatan pariwisata tersebut juga bertujuan menjaga kelestarian sumber daya alam (ekologi) dan budaya di Ponggok. Sejak BUMDes Ponggok menjalankan usaha ini pada 2009, desa ini bertransformasi menjadi desa yang mandiri dan masyarakatnya berdaya. Pada 2016, pendapatan asli desa melonjak hingga mencapai 10,5 milyar rupiah per tahun (Kaesthi, 2014).

Tulisan ini bertujuan menggambarkan model pengelolaan BUMDes Tirta Mandiri, hambatan dan tantangannya, serta perannya dalam meningkatkan taraf kesejahteraan masyarakat di Desa Ponggok.

\section{Kajian Pustaka}

Badan Usaha Milik Desa (BUMDes) adalah sebuah lembaga di desa yang menjalankan fungsi pengelolaan potensi dan aset desa; dan sebagai penyedia layanan usaha bagi masyarakat desa. BUMDes merupakan instrumen pendayagunaan ekonomi lokal dengan beragam jenis potensi. Pendayagunaan potensi ini terutama bertujuan untuk peningkatan kesejahteran ekonomi warga desa melalui pengembangan usaha ekonomi mereka. Di samping itu, keberadaan BUMDes juga memberikan sumbangan bagi peningkatan sumber pendapatan asli desa yang memungkinkan desa mampu melaksanakan pembangunan dan peningkatan kesejahteraan rakyat secara optimal (Ramadana, Ribawanto, dan Suwondo, 2013). Di balik tujuan BUMDes yang sangat baik, sangat disayangkan belum ada payung hukum bagi BUMDes. Saat ini, masalah BUMDes belum sepenuhnya diatur secara lengkap dalam peraturan perundang-undangan. Akibatnya BUMDes belum memiliki dasar legalitas yang kuat sebagai lembaga ekonomi desa. Padahal peran dan fungsi BUMDes sangat penting dalam meningkatkan taraf ekonomi warga masyarakat (Dewi, 2014). Pembentukan BUMDes dapat dilakukan dengan alokasi dana desa. Namun, hal ini tidak sepenuhnya dipahami oleh para kepala desa dan masyarakat. Penelitian Hehamahua (2015) menemukan 
bahwa seringkali, Alokasi Dana Desa (ADD) oleh pemerintah desa hanya difokuskan pada perbaikan fisik infrastruktur desa karena pandangan masyarakat saat ini pembangunan yang berhasil terpaku pada keadaan infrastruktur. Akibatnya, dana yang seharusnya dialokasikan untuk kegiatan yang produktif seperti BUMDes, Bank Desa, dan Pasar Desa sebagai penyedia pinjaman modal bergilir tanpa bunga bagi kegiatan pengembangan usaha kecil dan menengah justru digunakan untuk perbaikan konstruksi fisik desa (Hehamahua, 2015).

Implementasi BUMDes pun tidak mudah. Penelitian Budiono (2015) menemukan faktor-faktor yang berperan penting dalam implementasi kebijakan BUMDes dengan menampilkan contoh kasus BUMDes Ngringinrejo dan Kedungprimpen yang telah beroperasi sejak 2006 . Tulisan ini menemukan tiga faktor penting yang berperan, yaitu 1) aktor yang menjadi penggerak BUMDes, 2) karakteristik lembaga pemerintah desa yang memiliki pengaruh terhadap implementasi kebijakan BUMDes, dan 3) kepatuhan pelaksanaan BUMDes.

Aktor memegang peran yang penting dalam proses implementasi kebijakan BUMDes karena kepentingan aktor pelaksana kebijakan, baik kepentingan individu maupun kelompok, akan memengaruhi hasil kebijakan tersebut. Selain itu, karakteristik lembaga pemerintah desa juga berpengaruh terhadap hasil implementasi, sebab lembaga yang karakternya tertutup akan menghambat implementasi dan lembaga yang karakternya terbuka cenderung mendorong pelaksanaan kebijakan. Kepatuhan pelaksana kebijakan, pemerintah desa dalam mengadakan evaluasi, dan juga adanya laporan pertanggungjawaban melihat pelaksanaan kebijakan; serta peran dan respon pemerintah desa juga sangat berpengaruh dalam pelaksanaan kebijakan BUMDes.

Penelitian Ramadana, Ribawanto, dan Suwondo (2006) mengenai BUMDes di Desa Landungsari, Malang, menyajikan contoh kurang berfungsinya BUMDes. Alih-alih menjalankan peran dan fungsinya menyokong pendapatan desa, BUMDes di desa ini hanya sebatas papan nama saja.

Pelaksanaan BUMDes agar berujung pada pemberdayaan masyarakat memerlukan mobilisasi dari pemerintah desa dan partisipasi masyarakat. Mobilisasi masyarakat adalah salah satu tahapan dalam community organizing (pengorganisasian masyarakat) yang bertujuan menggerakkan masyarakat untuk mencapai cita-cita atau tujuan bersama. Pada tahap ini, masyarakat dilibatkan dalam proses perencanaan, pelaksanaan, dan evaluasi kegiatan yang dilaksanakan (Andini, 2013).

Partisipasi dapat diartikan sebagai keikutsertaan dalam suatu kegiatan kelompok, masyarakat, ataupun pemerintah. Menurut Ife (2006) partisipasi masyarakat merupakan hal penting dalam proses pemberdayaan masyarakat. Sebab, partisipasi merupakan bentuk kesadaran yang harus ada dalam diri individu sebagai syarat dalam terjadinya pemberdayaan masyarakat. Semakin tinggi tingkat partisipasi dan kesadaran masyarakat maka akan semakin ideal proses-proses inklusi yang hendak dicapai dan diwujudkan dalam proses pemberdayaan masyarakat (Ife, 2006).

Kegiatan pemberdayaan masyarakat merupakan model pembangunan alternatif yang menempatkan masyarakat sebagai subyek dengan menerapkan pendekatan bottom up. Namun, tidak semua kegiatan pemberdayaan masyarakat berhasil. Faktor penghambat keberhasilan biasanya adalah kurangnya fasilitas yang menunjang kegiatan pemberdayaan, kurangnya kontrol atau pendampingan terhadap subyek pemberdayaan, dan kurangnya keberlanjutan dari masyarakat dalam mengembangkan usaha yang diberdayakan adalah faktor-faktor yang dapat menghambat keberhasilan.

Di antara kegiatan pemberdayaan masyarakat yang berhasil adalah kegiatan di Desa Ped, Kecamatan Nusa Penida Kabupaten Klungkung, Bali; kegiatan di Kelurahan Ballaparang Kecamatan Rappocini, Makassar; kegiatan di Puncak, Bogor, Jawa Barat (Pradono, et al., 2016). Di Kelurahan Ped, kegiatan pemberdayaan masyarakat berupa pelatihan dan penyuluhan kesehatan ternak babi, pembuatan pakan 
ternak dengan teknologi fermentasi, pembuatan pupuk organik, pembuatan biogas, dan penyuluhan teknik pengeringan rumput laut. Program pemberdayaan masyarakat tersebut bertujuan memperkuat sistem pengelolaan usaha tani, serta meningkatkan produktivitas hasil pertanian (Surata dan Nindhia, 2016).

Kegiatan pemberdayaan masyarakat di Kelurahan Ballaparang, kecamatan Rappocini, Makassar berupa program pemberdayaan masyarakat untuk pengelolaan sampah. Kegiatan dilakukan melalui pemberian motivasi kepada masyarakat agar dapat bergerak lebih aktif dan inovatif dalam pengelolaan sampah (Jastam, 2015). Kegiatan pemberdayaan masyarakat di Puncak, Bogor dengan meningkatkan ekonomi masyarakat melalui sektor pariwisata di daerah Puncak, Bogor, Jawa Barat juga masuk kategori berhasil (Pradono et al., 2016).

\section{Metode}

Penelitian ini menggunakan metode penelitian kualitatif deskriptif. Metode penelitian kualitatif digunakan untuk mengkaji permasalahan yang holistik dan kompleks. Bogdan dan Taylor dalam Moleong (2007), mengemukakan bahwa metodologi kualitatif merupakan prosedur penelitian yang menghasilkan data deskriptif berupa kata-kata tertulis maupun lisan dari orang-orang dan perilaku yang diamati. Teknik pengumpulan data dilakukan melalui partisipasi obervasi pada kegiatan BUMDes di Desa Ponggok, wawancara mendalam dengan para pengelola BUMDes dan warga masyarakat, dan dokumentasi berupa foto dan video. Validitas data dijamin dengan teknik triangulasi data. Teknik analisis data meliputi, reduksi data, penyajian data, interpretasi, dan penarikan kesimpulan atau verifikasi.

\section{Hasil dan Pembahasan}

\section{Profil Desa Ponggok}

Desa Ponggok terletak di bagian timur laut Kota Klaten, sebelah barat stasiun kereta Delanggu. Lokasi desa berada 3 kilometer dari pusat kecamatan Polanharjo, dan 15 kilometer dari pusat ibu kota Kabupaten Klaten. Desa ini dapat diakses melalui jalan Yogyakarta Solo dengan kondisi jalan aspal yang halus. Desa ini juga terletak di lereng dan resapan air pertemuan dua pegunungan api aktif, yaitu Gunung Merapi dan Gunung Merbabu. Hal ini menyebabkan Ponggok memiliki potensi sumber daya alam berupa air yang melimpah.

Luas wilayah Desa Ponggok adalah 77.2225 hektar. Desa ini berbatasan dengan Desa Cokro, di sebelah utara, Desa Nganjat di sebelah timur, Desa Njeblog di sebelah selatan, dan Desa Dalangan di sebelah barat. Secara administrasi, desa ini terbagi dalam 4 dukuh yaitu Dukuh Umbulsari, Kiringan, Ponggok, dan Jemblogan. Jumlah 6 Rukun Warga ada 6 dan jumlah Rukun Tetangga ada 12.

Berdasarkan data monografi Desa Ponggok 2016, jumlah Kepala Keluarga di Desa Ponggok adalah 609 sedangkan jumlah penduduk mencapai 2.036 jiwa. Dari jumlah tersebut, terdapat 1.017 orang laki-laki dan 1.019 orang perempuan. Mayoritas penduduk Desa Ponggok beragama Islam. Sebagian kecil masyarakat beragaman Kristen dan Katholik. Pekerjaan warga sebagian besar adalah sebagai karyawan swasta yang bekerja pada perusahaan air minum swasta yang memanfaatkan sumber air di Ponggok. Tabel 1 di bawah ini menggambarkan komposisi jenis pekerjaan warga masyarakat Desa Ponggok:

\begin{tabular}{lll}
\hline No & Jenis pekerjaan & Jumlah \\
\hline 1 & Buruh tani & 17 orang \\
\hline 2 & Petani & 30 orang \\
\hline 3 & Pedagang & 93 orang \\
\hline 4 & PNS & 26 orang \\
\hline 5 & Karyawan & 420 orang \\
\hline 6 & Guru & 15 orang \\
\hline 7 & Wiraswasa & 123 orang \\
\hline 8 & Ibu rumah tangga & 217 orang \\
\hline 9 & Buruh harian & 198 orang \\
\hline 10 & Tidak bekerja & 194 orang \\
\hline Tabel & 1: Jumlah Penduduk menurut pekerjaan (Sum- \\
& ber: Monografi Desa Ponggok, 2016)
\end{tabular}

Latar belakang pendidikan warga masyarakat Desa Ponggok sebagian besar adalah tamatan sekolah menengah atas, sebagaimana tampak 
pada tabel 2 berikut:

\begin{tabular}{lll}
\hline No & Jenjang Pendidikan & Jumlah \\
\hline 1 & Taman Kanak-kanak & 60 orang \\
\hline 2 & Sekolah Dasar & 383 orang \\
\hline 3 & SMP/SLTP & 262 orang \\
\hline 4 & SMA/SLTA & 716 orang \\
\hline 5 & DI/II/III & 74 orang \\
\hline 6 & Sarjana (S1-S2) & 172 orang \\
\hline $\begin{array}{l}\text { Tabel 2: Jumlah Penduduk menurut tingkat pendidikan } \\
\text { (Sumber: Data Monografi Desa Ponggok, 2016) }\end{array}$
\end{tabular}

Sebagian besar penduduk Desa Ponggok (67.5\%) berada pada kategori usia produktif, sebagaimana tampak pada tabel 3 berikut:

\begin{tabular}{lll}
\hline No & Kategori Usia & Jumlah \\
\hline 1 & Usia muda (0-14 tahun) & 590 orang \\
\hline 2 & Usia produktif (15-64 tahun) & 1.672 orang \\
\hline 3 & Usia tua (65 tahun ke atas) & 215 orang \\
\hline
\end{tabular}
Tabel 3: Jumlah Penduduk menurut kategori usia (Sumber: Badan Pusat Statistik Kabupaten Klaten, 2016)

\section{Profil Usaha BUMDes Tirta Mandiri}

Pada 2009, Kepala Desa Ponggok, Pak Junaedi, sangat prihatin pada kondisi masyarakat Ponggok yang terlilit hutang pada rentenir dengan bunga tinggi. Kepala Desa kemudian berinisiatif menggunakan dana desa untuk melunasi hutang masyarakat Ponggok pada rentenir. Sisa dana desa digunakan untuk membuat usaha pengelolaan air bersih dengan melibatkan masyarakat. Pengelolaan ini kemudian diwadahi dalam BUMDes yang dinamai BUMDes Tirta Mandiri. Pembentukan BUMDes pada 2009 memang atas prakarsa Pak Junaedi yang menjabat sebagai kepala desa tetapi atas kesepakatan dan dukungan dengan warga.

Pengelolaan BUMDes berada di bawah Pemerintah Desa Ponggok. Tata kepengurusan Badan Usaha Milik Desa (BUMDes) Tirta Mandiri Ponggok tertuang dalam Anggaran Dasar dan Anggaran Rumah Tangga Badan Usaha Milik Desa (BUMDes) Tirta Mandiri Ponggok. Pada Bab VI Pasal 9 tentang Struktur Organisasi Badan Usaha Milik Desa (BUMDes) Tirta Mandiri Ponggok, BUMDes dipimpin oleh seorang direktur utama di bawah dewan komisaris dan diawasi oleh badan pengawas. Direktur dibantu oleh sekretaris dan bendahara BUMDes dalam melakukan tertib administrasi dan anggaran BUMDes. Selain itu, terdapat pula koordinator yang memantau di bagian lapangan, unit Umbul Ponggok, dan koordinator penyewaan yang memiliki tugas yang berbeda-beda dan didukung oleh bagian tiket, parkir, keamanan, kebersihan dan peralatan.

Pada awalnya bidang usaha BUMDes hanya dua, yaitu pengelolaan air bersih dan rintisan wisata umbul (mata air). Usaha pengelolaan air bersih dan rintisan wisata air dipilih karena sumber daya air yang melimpah di Desa Ponggok. Namun, sebagai upaya menggulirkan investasi, berbagai bidang usaha pun didirikan. Saat ini, unit usaha yang dimiliki Badan Usaha Milik Desa (BUMDes) Tirta Mandiri Ponggok terbagi dalam beberapa sektor seperti tampak pada tabel 4 berikut:

\begin{tabular}{lll}
\hline No & Unit usaha & $\begin{array}{l}\text { Tahun ber- } \\
\text { diri }\end{array}$ \\
\hline 1 & $\begin{array}{l}\text { Pengelolaan Air Bersih } \\
\text { (PAB) }\end{array}$ & 2009 \\
\hline 2 & Umbul Ponggok & 2009 \\
\hline 3 & Ponggok Ciblon & $\begin{array}{l}\text { September } \\
2016\end{array}$ \\
\hline 4 & Toko Desa & Juli 2016 \\
\hline 5 & Penyewaan Gedung & 2016 \\
\hline 6 & Kios Kuliner & 2016 \\
\hline $\begin{array}{l}\text { Tabel 4 : Periode berdirinya unit usaha BUMDes, } \\
\text { (Sumber : Data Monografi Desa Ponggok, 2016) }\end{array}$
\end{tabular}

Dua unit usaha pengelolaan obyek wisata air masuk dalam ketegori unit usaha pariwisata. Obyek wisata air terdiri atas Umbul Ponggok yang dikelola tahun 2009 dan Ponggok Ciblon yang didirikan pada Juli 2016 ( Gambar 1).

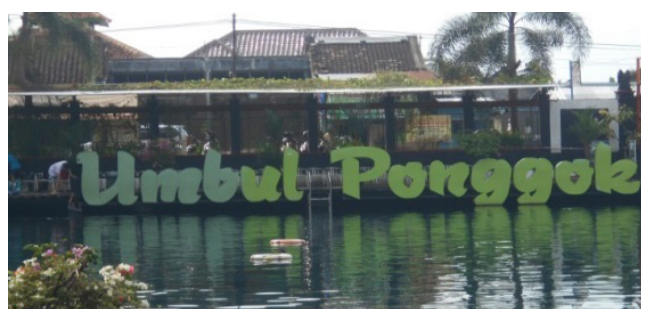

Gambar 1: Kolam Renang Umbul Ponggok (Sumber: Dokumentasi Peneliti, 2017) 
Pada bidang pengelolaan air bersih, BUMDes mengelola air bersih untuk dikonsumsi oleh masyarakat dengan harga Rp. 1.800,00 / meter kubik. Harga ini jauh lebih murah dari harga pasaran di luar Ponggok yang mencapai Rp. 3.000,00/ meter kubik.

Pada bidang usaha, BUMDes menyediakan penyewaan kios dagang bagi warga, berupa kios harian dan kios tahunan (gambar 2 dan gambar 3). Kios harian disewakan pada warga dengan biaya per hari yaitu Rp. 3.000,00; sedangkan kios tahunan disewakan dengan harga Rp. 2.500.000,00. Kios kuliner harian terletak di kawasan kantor Desa Ponggok sedangkan kios tahunan terletak di dalam kawasan Kolam Ponggok.

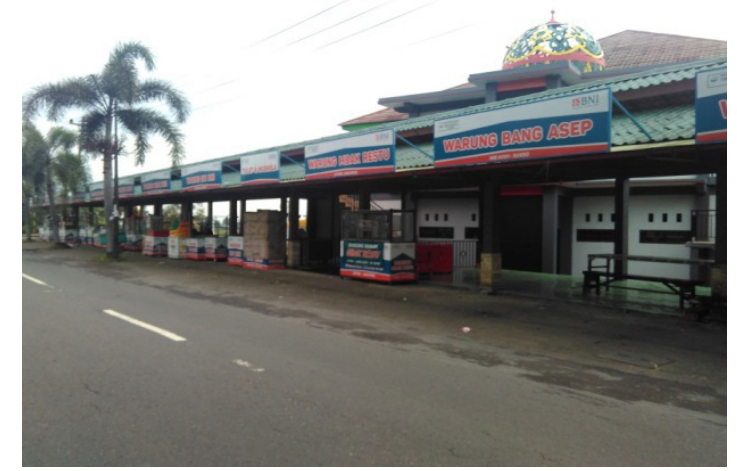

Gambar 2 : Kios Kuliner dengen biaya sewa harian (Sumber: Dokumentasi Peneliti, 2017)

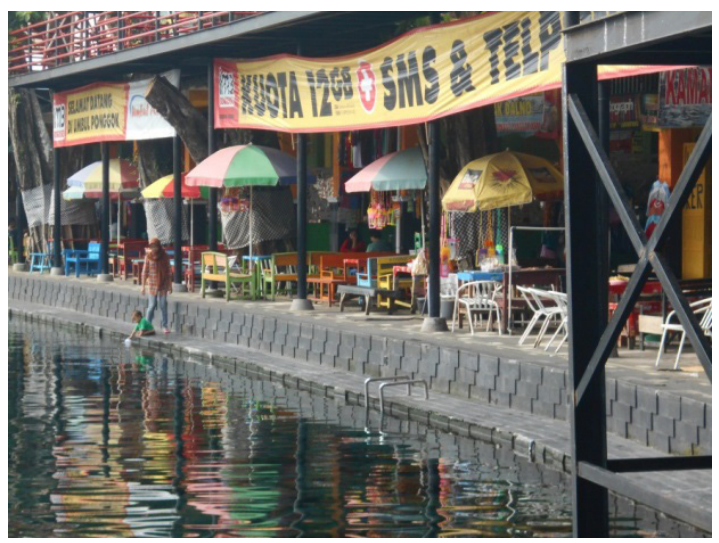

Gambar 3 : Penyewaan kios kuliner tahunan (Sumber: Dokumentasi Peneliti, 2017)

Unit usaha BUMDes lainnya adalah Toko Desa bernama "Rumah Pangan Kita". Toko ini didirikan sebagai wadah perputaran modal. Setiap warga masyarakat yang akan membuka usaha dagang, diperbolehkan mengambil kebutuhan barang di toko desa jika tidak mempunyai modal. Pinjaman modal barang ini jumlahnya senilai Rp. 500.000,00.

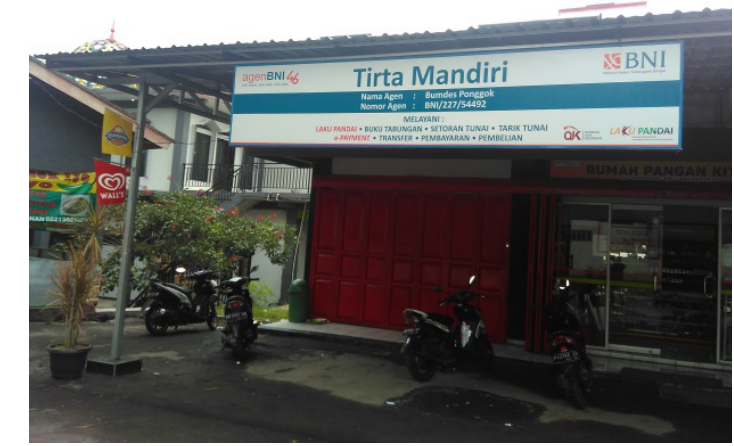

Gambar 4: Toko Desa (Sumber: Dokumentasi Peneliti, 2017)

Desa Ponggok juga memiliki gedung persewaan yang berada satu kawasan dengan Kantor Desa Ponggok dan penyewaannya dikelola oleh BUMDes. Gedung tersebut disewakan dengan harga Rp. 2.500.000,00 per hari. Gedung dilengkapi dengan panggung pertunjukan, meja, kursi, pendingin ruangan, mushola, dan juga area parkir yang luas.

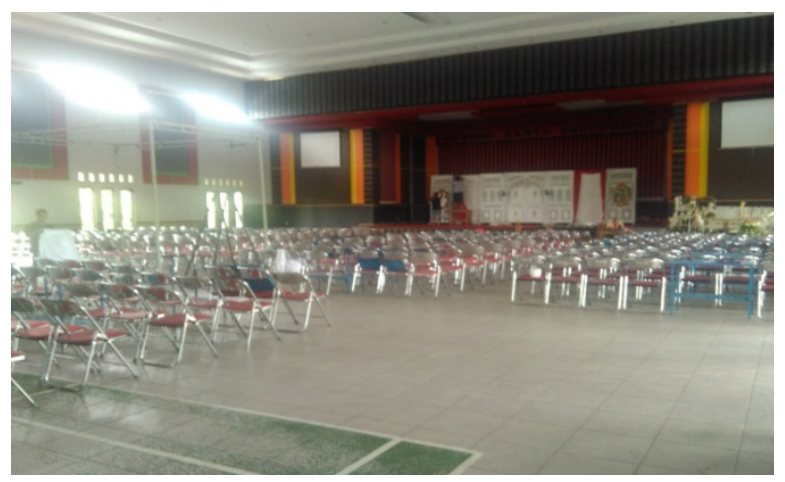

Gambar 5: Gedung persewaan milik BUMDes (Sumber: Dokumentasi Peneliti, 2017)

Pengelolaan Badan Usaha Milik Desa (BUMDes) Tirta Mandiri Ponggok diawasi dengan ketat. Hal ini karena permodalan yang dimiliki oleh BUMDes bersumber dari dana investasi yang berasal dari masyarakat. Pengurus berupaya untuk transparan dalam mengelola dana yang telah dihimpun oleh masyarakat. Oleh karenanya, terdapat badan pengawas BUMDes yang bertugas untuk mengawasi jalannya pelaksanaan dan pendanaan seluruh kegiatan unit usaha Badan Usaha Milik Desa (BUMDes) Tirta Mandiri Ponggok. Badan Pengawas BUMDes terdiri dari tiga orang. Pertanggungjawaban usaha 
BUMDes dilaporkan secara rutin setiap tahunnya. Pertanggungjawaban yang dilaporkan berupa laba rugi, neraca, dan perubahan modal. Pelaporan dilaksanakan paling lambat pada akhir bulan Januari setiap tahun. Melalui cara ini pengelolaan BUMDes menjadi lebih profesional. Selain itu, transparasi juga bertujuan memupuk kepercayaan masyarakat terhadap BUMDes.

Seluruh unit usaha BUMDes sangat berhasil. Pada masa awal rintisannya, BUMDes hanya memerlukan waktu tiga tahun untuk menunjukkan keberhasilannya. Pendapatan asli desa melonjak tajam melalui BUMDes, dari yang semula hanya 14 juta per tahun pada 2009, menjadi 150 juta pada 2012 dan meningkat lebih pesat lagi menjadi 600 juta pada 2013. Bahkan, pada 2014, pendapatan desa melesat hingga 1,1 milyar. Pada tahun yang sama, BUMDes Tirta Mandiri Ponggok berharap dapat mencapai pendapatan 3,8 milyar, tapi ternyata pendapatan yang diperoleh justru melampaui harapan yaitu mencapai 6,1 milyar. Desa Ponggok pun bertransformasi dari desa miskin ${ }^{1}$ menjadi desa yang mandiri dengan pendapatan 10,5 milyar rupiah pada tahun 2016 (lihat tabel 5). Capaian ini menjadikan Desa Ponggok sebagai percontohan desa mandiri di Indonesia.

\begin{tabular}{ll}
\hline Tahun & Pendapatan \\
\hline 2012 & 150 juta \\
\hline 2013 & 600 juta \\
\hline 2014 & 1,1 milyar \\
\hline 2015 & 6,1 milyar \\
\hline 2016 & 10,5 milyar \\
\hline
\end{tabular}

Tabel 5: Pendapatan BUMDes Ponggok sejak tahun 2012 sampai 2016 (Sumber: Monografi Desa Ponggok 2016)

\section{Faktor Pendorong dan Penghambat Penge- lolaan BUMDes}

Badan Usaha Milik Desa (BUMDes) Tirta Mandiri Ponggok yang dikembangkan oleh Pemerintah Desa Ponggok merupakan badan usaha yang disepakati dan dikembangkan bersama oleh masyarakat Desa Ponggok dengan tujuan pemberdayaan masyarakat. Di dalam proses pelaksanaannya tidak mudah karena banyak faktor yang mendorong dan menghambatnya.

Faktor yang mendorong berkembangnya Badan Usaha Milik Desa (BUMDes) Tirta Mandiri Ponggok adalah faktor teknologi. Perkembangan teknologi yang semakin pesat menyumbang andil yang besar. Badan Usaha Milik Desa (BUMDes) Tirta Mandiri Ponggok yang salah satu unit usahanya mengembangkan pariwisata, merasakan keuntungan dari berkembangnya teknologi. Antusias masyarakat yang tinggi akan perkembangan teknologi terutama media sosial mendorong mereka selalu ingin mendapatkan informasi baru melalui media sosial seperti instagram dan facebook, Pemerintah Desa Ponggok memanfaatkan media sosial untuk melakukan promosi wisata Umbul Ponggok. Cara ini sangat berhasil dalam mengundang wisatawan datang ke Ponggok.

Di dalam menjalankan programnya, pemerintah desa melibatkan masyarakat sebagai bentuk nyata pemberdayaan masyarakat. Keterlibatan masyarakat menjadi sasaran utama dalam pelaksanaan program BUMDes. Seluruh rencana pelaksanaan BUMDes diatur dalam ADART BUMDes Tirta Mandiri Ponggok. Unit usaha yang diatur dalam AD-ART BUMDes sebelumnya sudah tertuang dalam Rencana Pembangunan Jangka Menengah Desa (RPJMDes) Desa Ponggok.

Selain teknologi, faktor yang mendorong kesuksesan BUMDes Tirta Mandiri adalah sikap masyarakat dan pemerintah Desa yang ramah terhadap para pengunjung. Masyarakat dan pemerintah desa tidak sungkan dalam berbagi ilmu dan pengetahuan yang dimiliki terkait dengan suksesnya BUMDes Ponggok. Masyarakat dan pemerintah desa memfasilitasi masyarakat yang ingin berkunjung sebagai wisatawan ataupun yang ingin belajar tentang BUMDes Tirta Mandiri. Saat ini kunjungan dari berbagai instansi pemerintahan daerah untuk studi banding pengelolaan wisata dan BUMDes di Ponggok angat intensif. Setiap

1 Desa Miskin adalah desa dengan minimal 30\% penduduknya berada pada kategori ekonomi miskin/ pra sejahtera (Agusta, 2007). 
minggunya selalu ada 5-6 wakil pemerintahan dari berbagai kota yang datang berkunjung.

Di samping faktor pendorong, terdapat pula faktor yang menghambat pengelolaan BUMDES, yaitu tingkat pendidikan dan tingkat pemahaman politik di kalangan warga. Tingkat pendidikan yang masih rendah menjadi hambatan karena dalam membesarkan Badan Usaha Milik Desa (BUMDes) Tirta Mandiri Ponggok diperlukan tenaga kerja yang terdidik dan mempunyai keterampilan. Dari 88 pegawai yang bekerja di ponggok, hanya 3 yang lulusan sarjana dan lulusan SMA, SMP, dan SD.

Selain sumber daya manusia, persaingan usaha dengan pelaku usaha lain di desa juga merupakan hambatan dalam pengembangan BUMDes Tirta Mandiri di Desa Ponggok. Hasutan terhadap masyarakat tentang kurangnya kebermanfaatan beberapa program yang dilaksanakan BUMDes dan kesuksesan usaha selain BUMDes, mengakibatkan keyakinan warga pada BUMDes menurun.

\section{BUMDes dan Peningkatan Kesejahteraan Warga}

Unit kegiatan usaha BUMDes telah memberikan dampak terhadap perekonomian masyarakat. Dulu, warga masyarakat Ponggok adalah petani dan karyawan perusahaan air mineral. Kini, geliat unit usaha BUMDes Tirta Mandiri Ponggok telah berhasil menggeliatkan tingkat perekonomian warganya. Keterlibatan warga masyarakat dalam BUMDes membuat mereka mampu memenuhi kebutuhan hidup dan tidak lagi bergantung pada pinjaman rentenir.

BUMDes juga berperan sebagai fasilitator wirausaha warganya dengan memberikan bantuan modal barang untuk berdagang dan uang untuk modal usaha homestay. Selain itu, pendapatan BUMDes, membuat pemerintah desa membentuk program yang dapat dinikmati langsung oleh masyarakat. Hal ini bertujuan agar masyarakat Desa Ponggok dapat menikmati langsung keberadaan BUMDes. Program-program tersebut berupa jaminan sosial. Di antara program itu adalah jaminan lauk-pauk untuk lansia, jaminan kesehatan masyarakat, dan program satu rumah satu sarjana.

\section{Jaminan Uang Lauk Pauk untuk Lansia}

Tingkat kesejahteraan masyarakat di suatu daerah juga diindikasikan dengan pemenuhan kebutuhan baik pangan maupun pemenuhan fasilitas kesehatan. Hal tersebut juga dapat diukur dari pemenuhan kebutuhan hidup di masa tua dan pemenuhan kebutuhan akan kesehatan terhadap seluruh masyarakatnya.

Bentuk nyata dari hal ini adalah pemberian "Uang Lauk Pauk" kepada masyarakat Desa Ponggok yang berusia lanjut. Jumlah uang yang diberikan adalah Rp. $100.000,00$ per bulan. Uang bantuan ini diberikan karena orang berusia lanjut berhak mendapatkan perhatian khusus dari Pemerintah Desa. Hal ini sesuai dengan yang diungkapkan oleh Pak Sentot Adi Nugraha yang berprofesi sebagai kepala unit usaha BUMDes Toko Desa sebagai berikut:

"Pemerintah desa menyediakan tunjangan lauk pauk untuk lansia senilai 100.000 per bulan, biar kebutuhan nutrisi orang tua di Ponggok terpenuhi. Lagian juga mereka kan sudah tidak bisa bekerja sendiri. Maka dari itu kita sediakan uang lauk pauk seratus ribu per bulan." (Pak Sentot Edi Nugraha, Kepala Toko Desa, 16 April 2017)

\section{Jaminan Kesehatan Masyarakat}

Pemberian fasilitas pada warga merupakan upaya BUMDes membagi keuntungan usaha yang investasinya juga melibatkan masyarakat. Salah satu fasilitas yang diberikan adalah Jaminan Kesehatan Masyarakat. Hal ini diungkapkan oleh Pak Joko, direktur BUMDes:

"Kita kasih jaminan kesehatan kelas 3 untuk seluruh masyarakat ponggok tanpa terkecuali, kita cover semua. Untuk pegawai kita kasih kelas 1 . Kita ambil dari keuntungan dari BUMDes tapi tetep yang ngelola Desa. Semua masyarakat 
tanpa terkecuali." (Pak Joko, Direktur BUMDes Tirta Mandiri Ponggok, 17 April 2017)

Hal ini dibenarkan oleh masyarakat yang menerima jaminan kesehatan. Mereka menuturkan bahwa ketika mereka sakit, mereka benar-benar mendapatkan pengobatan secara gratis dan semua biayanya ditanggung oleh pemerintah desa melalui BPJS kelas tiga.

\section{Program Satu Rumah Satu Sarjana dan Ban- tuan Pendidikan}

Pemerintah desa membuat suatu program yang dapat memenuhi kebutuhan desa akan tenaga ahli dan pemerataan pendidikan. Program tersebut berupa Program Satu Rumah Satu Sarjana. Di dalam program ini, Pemerintah Desa Ponggok memberikan biaya pendidikan gratis setara S1 kepada Kepala Keluarga (KK). Setiap 1 orang dari satu KK diberikan kesempatan untuk menikmati program tersebut. Ibu Sari yang berprofesi sebagai Sekretaris Badan Usaha Milik Desa (BUMDes) Tirta Mandiri Ponggok menyatakan:

"Sekarang juga ada program 1 rumah satu sarjana. Semuanya dibayarin pemerintah desa. Dari biaya kuliah sampe uang sakunya per bulan dibiayai desa. Penginnya nanti kalo udah jadi sarjana mereka bakal ngolah desanya sendiri sampe BUMDes ini nantinya ada orang yang ngurusin. Terus buat anak SD, SMP, SMA semuanya ada jatah kaya beasiswa semuanya dari pemerintah desa dari 30, 50, 100 ribu biasanya di ambil 6 bulan sekali." (Bu Sari, Sekretaris BUMDes, 17 April 2017)

Pemerintah Ponggok juga memiliki program bantuan sekolah kepada masyarakat yang memiliki anak usia sekolah baik usia Sekolah Dasar (SD), Sekolah Menengah Pertama (SMP) dan Sekolah Menengah Atas (SMA) sederajat. Bantuan yang diberikan berupa dana bantuan pendidikan yang besarannya RP. 30.000,00 untuk usia Sekolah Dasar (SD), Rp. 50.000,00 untuk usia Sekolah Menengah Pertama (SMP), dan Rp. 100.000,00 untuk usia Sekolah Menengah Atas (SMA) sederajat.
Bantuan dana tersebut dapat diambil setiap enam bulan sekali.

\section{Simpulan}

Desa Ponggok berhasil mengembangkan Badan Usaha Milik Desa (BUMDes) untuk mengelola aset dan potensi desa yang kaya akan sumber air. Model pengelolaan BUMDes Tirta Mandiri dilakukan dengan terstruktur, transparan, dan melibatkan partisipasi masyarakat yang sangat tinggi.

Sikap masyarakat dan pemerintah desa yang saling bekerja sama, terbuka, dan ramah pada pendatang dan pemanfaatan teknologi yang maksimal menjadi faktor pendorong dalam keberhasilan pengelolaan BUMDes. Di sisi lain, persaingan dengan badan usaha jenis lain di desa, menjadi faktor penghambat. Namun, berkat partisipasi masyarakat yang tinggi dalam aneka unit pengelolaan usaha desa melalui BUMDes, hambatan berhasil diatasi. BUMDes mendorong terwujudnya masyarakat Desa Ponggok yang berdaya secara sosial dan secara ekonomi sehingga lebih sejahtera. Keberhasilan Desa Ponggok ini dapat menjadi contoh bagi pengembangan desa lainnya di Indonesia, yang menggabungkan prinsip sosial (yaitu partisipasi masyarakat) dengan prinsip ekonomi (yaitu pengelolaan unit usaha desa) sebagai upaya untuk memberdayakan masyarakat guna meningkatkan kesejahteraannya.

\section{Daftar Pustaka}

Agusta, I. (2007). Desa Tertinggal di Indonesia. Sodality: Jurnal Transdisiplin Sosiologi, Komunikasi, Dan Ekologi Manusia, 1(2), 233-252.

Andini, N. (2013). Pengorganisasian Komunitas dalam Pengembangan Agrowisata di Desa Wisata (Studi Kasus: Desa Wisata Kembangarum, Kabupaten Sleman). Jurnal Perencanaan Wilayah Dan Kota, 24(3), 173-188.

Badan Pusat Statistik Kabupaten Klaten. (2016). Kecamatan Polanharjo dalam Angka.

Budiono, P. (2015). Implementasi Kebijakan Badan Usaha Milik Desa (Bumdes). Jurnal Politik Muda, 4(1), 116-125.

Dewi, A. S. K. (2014). Peranan Badan Usaha Milik Desa (BUMDes) Sebagai Upaya dalam Meningkatkan Pendapatan Asli Desa 
(PADes) Serta Menumbuhkan Perekonomian Desa. Journal of Rural and Development, 5(1), 1-14.

Hehamahua, H. (2015). Impact Analysis of the Village Fund Allocation (ADD) Toward Economic Community (Case Study on the Rural District of Namlea Siahoni), Buru Regency Hayati. Journal of Social and Development Sciences, 6(3), 15-23

Ife, J. (2006). Community Development. Yogyakarta: Pustaka Pelajar.

Jastam, M. S. (2015). Pemberdayaan Masyarakat Melalui Pengelolaan Sampah (Studi Kasus di Bank Sampah Pelita Harapan, Kelurahan Ballaparang, Kecamatan Rappocini, Makassar). HIGIENE: Jurnal Kesehatan Lingkungan, 1(1), 42-48.

Kaesthi. (2014). Perubahan Sosial Budaya Masyarakat di Desa Wisata Karangbanjar Kabupaten Purbalingga. Solidarity: Journal of Education, Society and Culture, 3(1), 56-61.

Moleong, L. J. (2007). Metode Penelitian Kualitatif. Bandung: Remaja Rosdakarya.

Pemerintah Desa Ponggok. (2016). Monografi Desa Ponggok.

Pradono, P., Faisal, B., Adriani, Y., Rikeu, R., dan Fajriasanti, R. (2016). Towards Model of Community Economic Empowerment through Tourism Activities in Bogor Regency, West Java, Indonesia. International Journal of Economics and Financial Issues, 6(S6), 46-49.

Ramadana, C. B., Ribawanto, H., dan Suwondo. (2013). Keberadaan Badan Usaha Milik Desa (BUMDes) sebagai Penguatan Ekonomi Desa (Studi di Desa Landungsari, Kecamatan Dau, Kabupaten Malang). Jurnal Administrasi Publik (JAP), 1(6), 1068-1076.

Surata, I. W., dan Nindhia, T. G. T. (2016). Pemberdayaan Masyarakat melalui Pengembangan Kelompok Usaha Tani di Desa Ped. Jurnal Udayana Mengabdi, 15(1), 115-123. 